\title{
ANALYSIS OF SERUM LIPID PROFILE IN PATIENTS WITH PANCREATITIS
}

\author{
Yuvraj Kumar Churendra', Bhupati Bhusan Das 2 , Sushanta Kumar Das 3 , Niranjan Sahoo 4 , Mahammad Asfak Ahmed 5 , Charan Panda 6 \\ 1 Junior Resident, Department of General Surgery, M.K.C.G. Medical College \& Hospital, Berhampur, Odisha. \\ ${ }^{2}$ Assistant Professor, Department of General Surgery, M.K.C.G. Medical College \& Hospital, Berhampur, Odisha. \\ ${ }^{3}$ Professor, Department of General Surgery, (MCh. Neurosurgery), M.K.C.G. Medical College \& Hospital, Berhampur, Odisha. \\ ${ }^{4}$ Assistant Professor, Department of General Surgery, M.K.C.G. Medical College \& Hospital, Berhampur, Odisha. \\ ${ }_{5}^{5}$ Senior Resident, Department of General Surgery, M.K.C.G. Medical College \& Hospital, Berhampur, Odisha. \\ 6 Professor and HOD, Department of General Surgery, FAIS, FMAS, FCGP.
}

\section{ABSTRACT}

Pancreatitis is one of the most frequent gastrointestinal tract disease for hospitalization all over the world, leading to tremendous emotional, physical and financial human burden. The spectrum of aetiological factors for pancreatitis varies according to continents. Hyperlipidaemia is a rare but known and established risk factor for pancreatitis and goes undetected in most of the clinical settings. Early diagnosis of hyperlipidaemia induced pancreatitis is important to prevent its recurrence and complications.

\section{METHOD}

This is a prospective study carried out on patients with pancreatitis over a period of two years in M.K.C.G. Medical College and Hospital, Berhampur, Odisha, India. Fifty cases of pancreatitis of different age group and both sexes were selected. Equal number of age and sex matched patients other than pancreatitis were taken as control from the indoor. The mean serum lipid profiles of cases were compared with the control group.

\section{RESULT}

In this study it was observed that the Serum Total Cholesterol, Triglycerides, Low Density Lipoprotein and Very Low Density Lipoprotein were significantly higher in cases than controls, while HDL was found to be higher in controls. Young males were commonly affected and alcohol abuse is the most common risk factor followed by biliary stones.

\section{CONCLUSION}

All pancreatitis patients should be evaluated for any alteration in their serum lipid profile, if found to be treated with antilipidaemic drugs, dietary modulation, lifestyle change and physical exercise to limit the occurrence of this disease, pre vent its complications and to control the possibility of future recurrences.

\section{KEYWORDS}

Lipid Profile, Hyperlipidaemia, Pancreatitis.

HOW TO CITE THIS ARTICLE: Churendra YK, Das BB, Das SK, et al. Analysis of serum lipid profile in patients with pancreatitis. J. Evolution Med. Dent. Sci. 2016;5(43):2706-2709, DOI: 10.14260/jemds/2016/632

\section{INTRODUCTION}

The pancreatitis is one of the most frequent gastrointestinal tract cause of hospital admissions all over the world, leading to tremendous emotional, physical and financial human burdens. It may be acute in the beginning and lasting for a few days or chronic occurring over years. Chronic pancreatitis, although lower in incidence but significantly reduces patient's quality of life. The burden of pancreatitis is expected to increase over time due to changes in lifestyle of people. The risk and aetiology of pancreatitis differ in age and sex.[1] Hypertriglyceridaemia is relatively an uncommon cause of pancreatitis.

It has recently been shown that a significant proportion of patients with a history of acute pancreatitis have an abnormal clearance of exogenous triglycerides, indicating the

Financial or Other, Competing Interest: None.

Submission 13-04-2016, Peer Review 07-05-2016,

Acceptance 14-05-2016, Published 30-05-2016.

Corresponding Author:

Yuvraj Kumar Churendra,

C/o Prof. S. K. Das,

Department of Surgery,

MKCG Medical College \& Hospital

Berhampur-760004,

Odisha, India.

E-mail: yuvraj.churendra@gmail.com

skdas30@yahoo.com

DOI: $10.14260 /$ jemds/2016/632 presence of a pre-existent metabolic abnormality in this population. Pancreatitis secondary to hypertriglyceridaemia typically presents as an episode of acute pancreatitis or recurrent pancreatitis and rarely chronic pancreatitis. $[2,3]$ Hypertriglyceridaemia (HTG) is considered as a risk for pancreatitis when levels is $>1000 \mathrm{mg} / \mathrm{dL}$ (11.2 mmol/L). Early clinical recognition of HTG-Associated Pancreatitis (HTGP) is extremely important to provide appropriate therapy and to prevent further episodes.[3,4]

\section{METHODS}

The present study was undertaken in the Department of General Surgery, M.K.C.G. Medical College and Hospital, Berhampur, Odisha, India, prospectively from September 2013 to August 2015. The selection of cases and procedure adopted in this study are detailed below. Fifty consecutive cases of pancreatitis of different age group and both sexes were selected. Equal number of age and sex matched controls taken. The purpose of this study was explained to all the patients and control group participating in this study and written consent was taken from all. All presenting with clinical features of pancreatitis were admitted to the hospital and were subjected to routine blood investigations including serum amylase, lipase and radiological evaluation of abdomen. Out of them patients with evidence of pancreatitis were evaluated for serum lipid profile. 


\section{Inclusion Criteria}

1. Cases: 50 cases diagnosed with pancreatitis were included in the study.

2. Controls: 50 other patients admitted were included in the study (patient admitted with other surgical problems like hydrocele of TVT, hernia, varicose vein appendicitis, peptic ulcer, trauma case, intestinal perforation, cellulitis, etc. who are on oral diet and medication and without antilipidaemic medications).

\section{Exclusion Criteria}

1. Patients not willing for study.

2. Patients on antilipidaemic drugs.

3. Patients who are undergoing emergency interventions.

\section{OBSERVATIONS AND RESULTS}

Distribution of Risk Factors with Respect to Sex (Table 1 and Fig. 1)

In this study, the most common cause for pancreatitis was alcohol intake that constituted $46 \%$ of total. All patients were males. This was followed by gallstone in $28 \%$ incidence, out of which $10 \%$ were males and $18 \%$ were females. The data shows that alcohol intake is the major risk factor in males and gallstone in females. Hypertriglyceridaemia is found as a risk factor in 2 patients (4\%) one in each sex, trauma induced pancreatitis was found in 1 patient (2\%) who was a female. Iatrogenic induced pancreatitis was found in 2 patients (4\%) who had undergone ERCP elsewhere and both were females. Tumour was responsible in 3 patients (6\%) one was male and two were females, Drug (corticosteroid) was found to be a risk factor in 1 patient (2\%) who was a female and idiopathic pancreatitis was found in 4 patients (8\%) and all were females.

\begin{tabular}{|c|c|c|c|}
\hline Risk Factor & Male & Female & Total \\
\hline Alcohol & $23(46 \%)$ & $00(00 \%)$ & $23(46 \%)$ \\
\hline GB stone & $05(10 \%)$ & $09(18 \%)$ & $14(28 \%)$ \\
\hline HTG & $01(2 \%)$ & $01(2 \%)$ & $02(4 \%)$ \\
\hline Trauma & $00(0 \%)$ & $01(2 \%)$ & $01(2 \%)$ \\
\hline Iatrogenic & $00(0 \%)$ & $02(4 \%)$ & $02(4 \%)$ \\
\hline Tumour & $01(2 \%)$ & $02(4 \%)$ & $03(6 \%)$ \\
\hline Drug & $00(0 \%)$ & $01(2 \%)$ & $01(2 \%)$ \\
\hline Idiopathic & $00(0 \%)$ & $04(8 \%)$ & $04(8 \%)$ \\
\hline Table 1: Distribution of Risk Factors with Respect to Sex \\
\hline
\end{tabular}

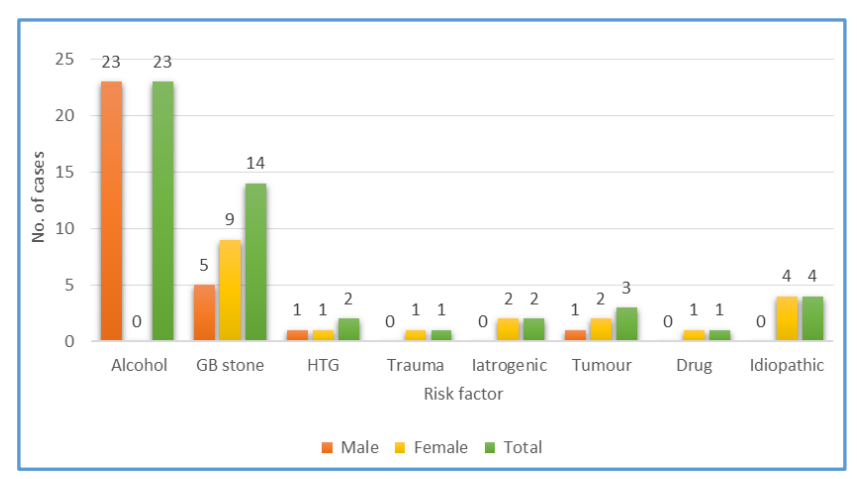

Fig. 1: Distribution of Risk Factors with Respect to Sex Distribution of Risk Factors in Acute and Chronic Pancreatitis (Table 2 and Fig. 2)
It was observed that the most common risk factor for acute pancreatitis was alcohol consumption that comprising of 16 patients out of 31 patients (51.6\%), while gall stone was common risk factors for chronic pancreatitis that constituted 9 patients (47.4\%). Hypertriglyceridaemia, trauma, iatrogenic, tumour, drugs and idiopathic factors were responsible for acute pancreatitis in 2, 1, 2 1, 1 and 3 number of patients respectively. Tumour and idiopathic factors were responsible for chronic pancreatitis in 2 and 1 patients respectively.

\begin{tabular}{|c|c|c|}
\hline Risk Factor & $\begin{array}{c}\text { Acute } \\
\text { Pancreatitis } \\
(\mathbf{n = 3 1 )}\end{array}$ & $\begin{array}{c}\text { Chronic } \\
\text { Pancreatitis } \\
(\mathbf{n = 1 9 )}\end{array}$ \\
\hline Alcohol & $16(32 \%)$ & $07(14 \%)$ \\
\hline Gall stone & $05(10 \%)$ & $09(18 \%)$ \\
\hline HTG & $02(4 \%)$ & $00(0 \%)$ \\
\hline Trauma & $01(2 \%)$ & $00(0 \%)$ \\
\hline Iatrogenic & $02(4 \%)$ & $00(0 \%)$ \\
\hline Tumour & $01(2 \%)$ & $02(4 \%)$ \\
\hline Drug & $01(2 \%)$ & $00(0 \%)$ \\
\hline Idiopathic & $03(6 \%)$ & $01(2 \%)$ \\
\hline Table 2: Distribution of Risk Factors with Respect to \\
\multicolumn{2}{|c|}{ Acute and Chronic Pancreatitis } \\
\hline
\end{tabular}

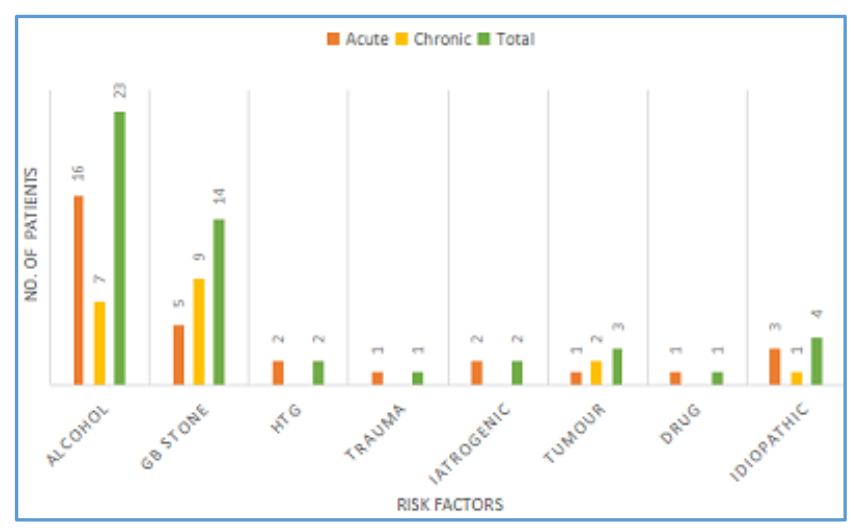

Fig. 2: Distribution of Risk Factors with Respect to Acute and Chronic Pancreatitis

Serum Lipid Profile of Case versus Control Group (Table 3 and Fig. 3)

Table 3 shows the mean serum value of T-C, TG, HDL-C, LDL-C and VLDL-C in cases, which were compared with the same variables of control group.

It was observed from the table that the mean serum T-C in cases were $159.74 \mathrm{mg} / \mathrm{dL}$, while the same in controls was $132.18 \mathrm{mg} / \mathrm{dL}$, the mean serum TG in cases were 179.56 $\mathrm{mg} / \mathrm{dL}$, while it was $122.54 \mathrm{mg} / \mathrm{dL}$ in controls. The mean HDL$\mathrm{C}$ in cases was $36.83 \mathrm{mg} / \mathrm{dL}$ and it was $39.20 \mathrm{mg} / \mathrm{dL}$ in controls. The mean serum LDL-C and VLDL-C in cases were $90.19 \mathrm{mg} / \mathrm{dL}$ and $35.20 \mathrm{mg} / \mathrm{dL}$ respectively, while in controls it was $71.42 \mathrm{mg} / \mathrm{dL}$ and $29.46 \mathrm{mg} / \mathrm{dL}$ respectively. It was observed from the Table 12 that serum T-C level in cases were $159.74 \mathrm{mg} / \mathrm{dL}$, which is higher by about $27.56 \mathrm{mg} / \mathrm{dL}$ than the controls. TG was found to be raised by $57.02 \mathrm{mg} / \mathrm{dL}$ when compared with control. The serum LDL-C level was found to be higher by $18.77 \mathrm{mg} / \mathrm{dL}$ in cases, while serum VLDL-C level is higher by $5.74 \mathrm{mg} / \mathrm{dL}$ in cases. HDL-C level is $2.37 \mathrm{mg} / \mathrm{dL}$ higher in control group. Values of T-C, TG, HDL-C, LDL-C and VLDL-C were more than the two standard deviation of control group. 


\begin{tabular}{|c|c|c|c|c|c|c|}
\hline Group & Total & $\begin{array}{c}\text { T-C } \\
\text { Mean } \pm \text { 2SD } \\
(\mathbf{m g} / \mathbf{d L})\end{array}$ & $\begin{array}{c}\text { TG } \\
\text { Mean } \pm \text { 2SD } \\
(\mathbf{m g} / \mathbf{d L})\end{array}$ & $\begin{array}{c}\text { HDL-C } \\
\text { Mean } \pm \text { 2SD } \\
(\mathbf{m g} / \mathbf{d L})\end{array}$ & $\begin{array}{c}\text { LDL-C } \\
\text { Mean } \pm 2 \text { 2SD } \\
(\mathbf{m g} / \mathbf{d L})\end{array}$ & $\begin{array}{c}\text { VLDL-C } \\
\text { Mean } \pm 2 S D \\
(\mathbf{m g} / \mathbf{d L})\end{array}$ \\
\hline Case & 50 & $159.74 \pm 39.01$ & $179.56 \pm 83.31$ & $36.83 \pm 7.67$ & $90.19 \pm 25.63$ & $35.20 \pm 9.50$ \\
\hline Control & 50 & $132.18 \pm 23.93$ & $122.54 \pm 37.10$ & $39.20 \pm 8.49$ & $71.42 \pm 19.21$ & $29.46 \pm 7.66$ \\
\hline \multicolumn{7}{|c|}{ Table 3: Comparison of Serum Lipid Profile of Case and Control Group } \\
\hline
\end{tabular}

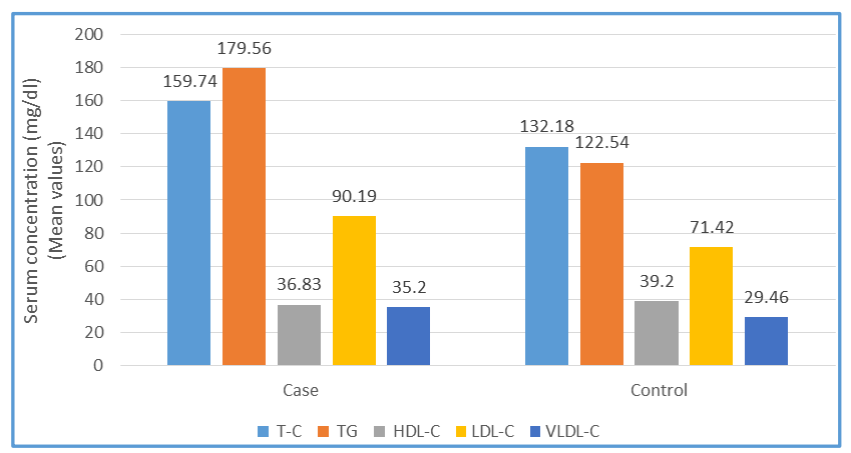

Fig. 3: Comparison of Serum Lipid Profile of Case and Control Group
Comparison of Serum Lipid Profile of Patients with Acute and Chronic Pancreatitis (Table 4 and Fig. 4)

The mean serum T-C, TG, HDL-C, LDL-C and VLDL-C in acute pancreatitis were $157.26 \mathrm{mg} / \mathrm{dL}, 166.90 \mathrm{mg} / \mathrm{dL}, 33.54 \mathrm{mg} / \mathrm{dL}$, $89.32 \mathrm{mg} / \mathrm{dL}$ and $33.19 \mathrm{mg} / \mathrm{dL}$ respectively, while it was $163.79 \mathrm{mg} / \mathrm{dL}, 200.21 \mathrm{mg} / \mathrm{dL}, 36.07 \mathrm{mg} / \mathrm{dL}, 91.62 \mathrm{mg} / \mathrm{dL}$ and $38.47 \mathrm{mg} / \mathrm{dL}$ respectively in chronic pancreatitis. Table 4 shows that all the parameters were higher in chronic pancreatitis. It was observed that T-C is higher by $6.53 \mathrm{mg} / \mathrm{dL}$, TG is higher by $33.31 \mathrm{mg} / \mathrm{dL}$, HDL-C was higher by $2.53 \mathrm{mg} / \mathrm{dL}$, LDL-C was by $2.3 \mathrm{mg} / \mathrm{dL}$ and VLDL-C was higher by 5.28 $\mathrm{mg} / \mathrm{dL}$.

\begin{tabular}{|c|c|c|c|c|c|}
\hline Pancreatitis & $\begin{array}{c}\text { T-C } \\
\text { Mean } \pm \text { 2SD } \\
(\mathbf{m g} / \mathbf{d L})\end{array}$ & $\begin{array}{c}\text { TG } \\
\text { Mean } \pm \text { 2SD } \\
(\mathbf{m g} / \mathbf{d L})\end{array}$ & $\begin{array}{c}\text { HDL-C } \\
\text { Mean } \pm 2 \text { SD } \\
(\mathbf{m g} / \mathbf{d L})\end{array}$ & $\begin{array}{c}\text { LDL-C } \\
\text { Mean } \pm 2 S D \\
\text { (mg/dL) }\end{array}$ & $\begin{array}{c}\text { VLDL-C Mean } \pm 2 S D \\
\text { (mg/dL) }\end{array}$ \\
\hline Acute & $157.26 \pm 37.23$ & $166.90 \pm 76.27$ & $33.54 \pm 7.65$ & $89.32 \pm 28.88$ & $33.19 \pm 8.22$ \\
\hline Chronic & $163.79 \pm 42.48$ & $200.21 \pm 92.06$ & $36.07 \pm 9.25$ & $91.62 \pm 19.89$ & $38.47 \pm 10.71$ \\
\hline \multicolumn{7}{|r}{} \\
\hline
\end{tabular}

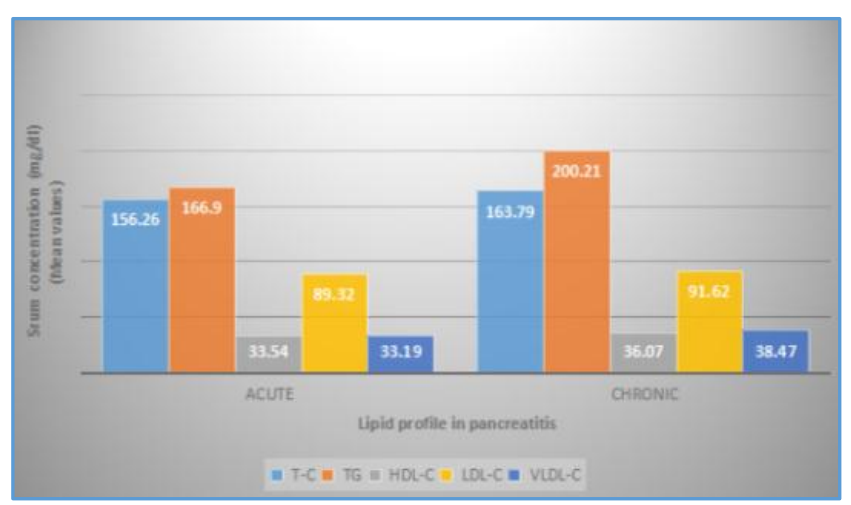

Fig. 4: Comparison of Serum Lipid Profile of Patients with Acute and Chronic Pancreatitis

\section{Lipid Profile in Males (Table 5)}

In this study it was observed that the lipid profile in male case group i.e. serum T-C, TG, LDL-C and VLDL-C are $159.50 \mathrm{mg} / \mathrm{dl}$, $185.40 \mathrm{mg} / \mathrm{dl}, 89.53 \mathrm{mg} / \mathrm{dl}$ and $36.46 \mathrm{mg} / \mathrm{dl}$ and were higher than the control group. In control group the serum concentration of T-C, TG, LDL-C and VLDL-C are $133.32 \mathrm{mg} / \mathrm{dl}$, $126.58 \mathrm{mg} / \mathrm{dl}, 69.64 \mathrm{mg} / \mathrm{dl}$ and $30.61 \mathrm{mg} / \mathrm{dl}$. Only parameter serum HDL-C was higher in control group than cases, in the former it was $39.54 \mathrm{mg} / \mathrm{dl}$ and in the latter it was $36.03 \mathrm{mg} / \mathrm{dl}$.

\begin{tabular}{|c|c|c|c|}
\hline $\begin{array}{c}\text { Sl. } \\
\text { No. }\end{array}$ & Variables & $\begin{array}{c}\text { Case } \\
\text { Mean } \pm 2 S D \\
(\mathbf{m g} / \mathbf{d L})\end{array}$ & $\begin{array}{c}\text { Control } \\
\text { Mean } \pm 2 S D \\
(\mathbf{m g} / \mathbf{d L})\end{array}$ \\
\hline 1. & T-C & $159.50 \pm 30.29$ & $133.32 \pm 30.05$ \\
\hline 2. & TG & $185.40 \pm 92.35$ & $126.58 \pm 40.02$ \\
\hline 3. & HDL-C & $36.03 \pm 7.49$ & $39.54 \pm 8.04$ \\
\hline 4. & LDL-C & $89.53 \pm 23.09$ & $69.64 \pm 21.47$ \\
\hline 5. & VLDL-C & $36.46 \pm 8.49$ & $30.61 \pm 7.78$ \\
\hline \multicolumn{4}{r}{ Table 5: Lipid Profile in Males } \\
\hline
\end{tabular}

\section{Lipid Profile of Females (Table 6)}

The mean serum lipid profile parameters in females, i.e. T-C, TG, HDL-C, LDL-C and VLDL-C were $160.10 \mathrm{mg} / \mathrm{dL}, 170.80$ $\mathrm{mg} / \mathrm{dL}, \quad 38.02 \mathrm{~g} / \mathrm{dL}, \quad 91.19 \mathrm{mg} / \mathrm{dL}$ and $33.30 \mathrm{mg} / \mathrm{dL}$ respectively. The same parameters in control group was $130.32 \mathrm{mg} / \mathrm{dL}, 115.95 \mathrm{mg} / \mathrm{dL}, 38.63 \mathrm{mg} / \mathrm{dL}, 74.31 \mathrm{mg} / \mathrm{dL}$ and $27.57 \mathrm{mg} / \mathrm{dL}$ respectively. All the parameters were higher in case group than control group except serum HDL-C.

\begin{tabular}{|c|c|c|c|}
\hline $\begin{array}{c}\text { Sl. } \\
\text { No. }\end{array}$ & Variables & $\begin{array}{c}\text { Case } \\
\text { Mean } \pm 2 S D \\
(\mathbf{m g} / \mathbf{d L})\end{array}$ & $\begin{array}{c}\text { Control } \\
\text { Mean } \pm 2 S D \\
\text { (mg/dL) }\end{array}$ \\
\hline 1. & T-C & $160.10 \pm 50.23$ & $130.32 \pm 21.52$ \\
\hline 2. & TG & $170.80 \pm 68.92$ & $115.95 \pm 31.67$ \\
\hline 3. & HDL-C & $38.02 \pm 7.99$ & $38.63 \pm 9.37$ \\
\hline 4. & LDL-C & $91.19 \pm 29.65$ & $74.31 \pm 14.91$ \\
\hline 5. & VLDL-C & $33.30 \pm 10.79$ & $27.57 \pm 7.27$ \\
\hline \multicolumn{4}{|c}{ Table 6: Lipid Profile in Females } \\
\hline
\end{tabular}

\section{DISCUSSION}

\section{Age and Sex Distribution}

The youngest patient in this study was 16-year-old female and oldest one was 60-year-old female. The mean age of presentation in overall cases was 36.92 years. The mean age of presentation in male it was 36.76 years, while it was 37.15 years in female patient. The bulk of the disease is almost equal in two age groups, that is age group 26-35 years and 36-45 years with $34 \%$ and $36 \%$ (Total $70 \%$ ) of incidence respectively with male preponderance of $48 \%$. Pancreatitis is less common in age groups 15-25 years and 46-55 years that constitute $12 \%$ and $16 \%$ respectively of total and incidence decreases with advancing age. This study is correlated with that study of Teshima et al and Yadav et al. ${ }^{[5,6]}$ According to this 
study, the peak incidence of pancreatitis for both men and women is between 40 and 70 years of age with a male predominance in all age groups.

\section{Risk Factor Distribution}

In our study, the most common risk factor for pancreatitis is alcohol abuse and accounts for $46 \%$ of total cases followed by gallstone disease in $30 \%$ cases. But in western literature, the most common risk factor for pancreatitis is gall stone disease followed by alcohol abuse. Our study correlated with study of Baig SJ et al.[7] In their study, the incidence of alcohol induced pancreatitis was $41.1 \%$, gall stone accounted for $23.5 \%$ and $36 \%$ were idiopathic. Hypertriglyceridaemia is found as a risk factor in 2 patients (4\%) one in each sexes, trauma induced was in 1 patient (2\%) who was a female, iatrogenic induced pancreatitis was found in 2 patients $(4 \%)$ and both were females. Tumour was responsible in 3 patients $(6 \%)$ one was male and two were females, Drug (Corticosteroid) was found to be risk factor in 1 patient (2\%) who was a female. Idiopathic pancreatitis was noted in $8 \%$ cases.

\section{Comparison of Lipid Profile in Case and Control Group}

In this study, it was observed that the lipid profile was altered in case group when compared with control group. The mean serum values of T-C, TG, HDL-C, LDL-C and VLDL-C in case group were recorded. It was observed that the mean T-C level in cases was found to be $159.74 \mathrm{mg} / \mathrm{dL}$ with standard deviation of 39.05. Mean serum TG in cases, it was found to be $179.56 \mathrm{mg} / \mathrm{dL}$ with standard deviation 83.31. Mean HDL-C was found to be $36.83 \mathrm{mg} / \mathrm{dL}$ with standard deviation 7.67 . Mean serum level of LDL-C was found to be $90.19 \mathrm{mg} / \mathrm{dL}$ with standard deviation 25.63 and mean serum level of VLDL-C was $35.20 \mathrm{mg} / \mathrm{dL}$ with standard deviation 9.50. In control group, it was observed that the mean serum value of T-C, TG, HDL-C, LDL-C and VLDL-C in control was $132.18 \mathrm{mg} / \mathrm{dL}, 122.54$ $\mathrm{mg} / \mathrm{dL}, 39.20 \mathrm{mg} / \mathrm{dL}, 71.42 \mathrm{mg} / \mathrm{dL}$ and $29.46 \mathrm{mg} / \mathrm{dL}$ respectively with Standard Deviation (SD) 26.93, 37.10, 8.49, 19.21 and 7.66 respectively. All the parameters are higher in case group than control group except serum HDL. The clinical study of Michalakis K. et al concludes that the lipid profile revealed an impressive elevation of triglycerides and cholesterol that support our observation and other study says that there is marked decrease in serum HDL-C in pancreatitis, which is consistent with our study.[8]

\section{Distribution of Cases on the Basis of BMI}

In this study the mean BMI of case group is higher, i.e. 22.64 $\mathrm{kg} / \mathrm{m}^{2}$, while it is $21.10 \mathrm{~kg} / \mathrm{m}^{2}$ in control group. It was observed that out of 50 patients $16(32 \%)$ were underweight, $18(36 \%)$ were normal, 12 (24\%) were overweight and 04 $(8 \%)$ were obese. Many studies have been conducted whether obesity affects the pathogenesis of pancreatitis or not, but no evidence has been accumulated in the past two decades. In this study $8 \%$ patients were obese, but its effect on natural history of pancreatitis could not be established. The percentage of obesity was higher in pancreatitis patient.

\section{CONCLUSION}

\section{From this Study it is Concluded that}

1. Males are more commonly affected with pancreatitis than females.
2. Pancreatitis is more common in young adults between 25-40 years of age group.

3. The incidence of acute pancreatitis cases are more than chronic pancreatitis.

4. In general, alcohol intake is the most common risk factor for pancreatitis followed by gall stone disease.

5. Alcohol consumption is the commonest risk factor for acute pancreatitis, whereas gall stone disease is the commonest risk factor for chronic pancreatitis.

6. The parameters of lipid profile namely TC, TG, LDL-C and VLDL-C are higher and serum HDL-C is lower in pancreatitis patient than control group.

7. All the parameters of lipid profile compared among pancreatitis patients is that, the values are much higher in chronic pancreatitis than in acute pancreatitis.

8. Percentage of obesity (BMI $>30 \mathrm{~kg} / \mathrm{m}^{2}$ ) was higher in pancreatitis patient.

Finally, it is concluded that pancreatitis is commonly associated with alcohol intake, gall stone and altered serum lipid profile. Therefore, patient with above risk factors needs to be evaluated for any alteration in their serum lipid profile; if found to be treated with antilipidaemic drugs, dietary modulation, life style change and physical exercise in order to limit the risk of occurrence of this disease prevent its inherent complications and to control the possibility of future recurrences.

\section{REFERENCES}

1. Yadav D, Lowenfels AB. The epidemiology of pancreatitis and pancreatic cancer. Gastroenterology 2013;144(6):1252-61.

2. Gan SI, Edwards AL, Symonds CJ, et al. Hypertriglyceridemia-induced pancreatitis: a case-based review. World J Gastroenterol 2006;12(44):7197-202.

3. Kota SK, Jammula S, Krishna SVS, et al. Hypertriglyceridemia-induced recurrent acute pancreatitis: a case-based review. Indian J Endocrinol Metab 2012;16(1):141-3.

4. Graesdal A. Severe hypertriglyceridemia--an important cause of pancreatitis. Tidsskr Nor Laegeforen 2008;128(9):1053-6.

5. Yadav D, Timmons L, Benson JT, et al. Incidence, prevalence, and survival of chronic pancreatitis: a population-based study. Am J Gastroenterol 2011;106(12):2192-9.

6. Teshima CW, Bridges RJ, Fedorak RN. Canadian digestive health foundation public impact series 5: pancreatitis in Canada. Incidence, prevalence, and direct and indirect economic impact. Can J Gastroenterol 2012;26(8):544-5.

7. Baig SJ, Rahed A, Sen S. A prospective study of the aetiology, severity and outcome of acute pancreatitis in Eastern India. Trop Gastroenterol 2008;29(1):20-2.

8. Michalakis K, Basiakou E, Xanthos T, et al. Lipemic serum in hyperlipidemic pancreatitis. Cases J 2009;2:198. Doi: 10, 1186/1757-1626-2-198. 